Images vol. XIV/no. 23

Poznań 2014

\section{Autobus Linkego jako parodia PRL. Studium intertekstualne}

Obraz Bronisława Wojciecha Linkego Autobus należy do najwybitniejszych, szczególnie doniosłych znaczeniowo dzieł sztuki polskiej okresu PRL. Powstał nie od razu, tworzony był etapami. Malarz pracował nad nim przez sześć lat: rozpoczął malowanie w roku 1955, a więc w czasach politycznej Odwilży, wznowił prace w roku 1959 i ostatecznie ukończył go na krótko przed śmiercią. Znaczący ślad tego procesu dojrzewania artysta utrwalił i pozostawił w prawym dolnym rogu obrazu, gdzie oprócz sygnatury autora płótna widnieje dopisek: 1955, a pod nim: 1959-1961.

Nie całkiem zapomniane, lecz przecież prawie nieobecne - nie tylko w świadomości zbiorowej, ale nawet w pamięci współczesnych historyków sztuki, niezwykłe dzieło Linkego jest czymś więcej niż jednym ze znakomitych dokonań sztuki polskiej, należącym do klasyki rodzimego malarstwa okresu PRL. Osobiście uważam je za osiągnięcie artystyczne najwyższej klasy, godne porównania z dwoma powstałymi dokładnie w tym samym czasie innymi arcydziełami tamtego okresu: Zezowatym szczęściem (1959-1960) Andrzeja Munka oraz Kartoteka (1960) Tadeusza Różewicza.

Na wskazaną wyżej nikłą obecność dzieła Linkego w zbiorowej świadomości i pamięci złożyło się wiele przyczyn. Dziewięć lat po śmierci artysty, który zmarł w roku 1962, Autobus zakupiło Muzeum Narodowe w Warszawie. W zbiorach muzeum obraz figuruje pod numerem inwentaryzacyjnym MPW 1045. O ile mi wiadomo, w latach 70. przez dłuższy czas ze względów politycznych pozostawał on kłopotliwym prohibitem. Niewiele również - jak na tej klasy obraz - mówiło się o nim i pisało, nie był też nigdzie publicznie prezentowany. Dzisiaj odkryte na nowo arcydzieło Linkego wchodzi jak najsłuszniej w skład stałej ekspozycji stołecznego Muzeum Narodowego, która nosi zobowiązujący tytuł „Sztuka polska XX i XXI wieku”.

Wspaniały obraz Bronisława Linkego to jednak nie tylko eksponat muzealny. Po dzień dzisiejszy dostarcza on twórczej inspiracji - wywoływany i przypominany przy różnych okazjach: na przykład w znanej piosence Jacka Kaczmarskiego czy na okładce jednej z powieści Jerzego Pilcha Marsz Polonia[1]. Nieprzypadkowo też Autobus zajął eksponowane miejsce na słynnej wystawie „Polaków portret własny”, zaprezentowanej w roku $1981 \mathrm{w}$ salach Muzeum Narodowego w Kra-

[1] J. Pilch, Marsz Polonia, Świat Książki - Bertels-

mann Media, Warszawa 2008.
Uwagi wstępne 
kowie. Był jak znalazł - jako wymowne świadectwo kontrkulturowych aspiracji sztuki społecznie zaangażowanej, tworzonej przez wybitnych artystów w czasach Polski Ludowej.

Artystą zafascynowanym płótnem Linkego okazał się wspomniany przed momentem Jacek Kaczmarski, którego piosenka pt. Czerwony autobus stanowi sugestywną transpozycję tego obrazu - rodzaj śpiewanej interpretacji wyrosłej z głęboko osobistego przeżycia barda („Pędzimy przez polską dzicz. Wertepy, chaszcze, błota. Patrz w tył - tam nie ma nic. Żałoba i sromota”). Do piosenki Kaczmarskiego wypadnie nam jeszcze parokrotnie powrócić w dalszej części rozważań. Na razie postawmy pytanie o gatunek malarski, do którego odwołuje się i którym operuje obraz Linkego.

Panorama

Z gatunkowego punktu widzenia Autobus można zaklasyfikować jako szczególnego rodzaju odmianę portretu grupowego we wnętrzu. O reprezentatywności ukazanej w nim grupy ludzi, egzemplarycznej pod wieloma względami, powiemy szerzej za chwilę. W tym miejscu spróbujmy umownie określić obraz Linkego jako panoramę (gr. pan- 'wszech', 'wszystko', hórama - 'widok', 'widowisko'), mając na uwadze trzy znamienne cechy obrazu: po pierwsze - złudzenie rozległości i głębi ukazanej przestrzeni, po drugie - ruch służący zorientowaniu obserwatora w otoczeniu, i po trzecie - przemyślną aranżację postaci, mikrosytuacji i wszelkich realiów, podporządkowaną obserwowaniu poruszającego się obiektu.

Zadziwiające, że malarz zdołał pomieścić - i z niezrównaną precyzją każdego detalu ukazać - aż tyle postaci, rekwizytów i sytuacji $\mathrm{w}$ tak niewielkim formacie. W zestawieniu z płótnami Siemiradzkiego czy Matejki jego obraz wydaje się niemal malarską miniaturą, czymś w rodzaju minipanoramy. Stosunkowo niewielkie wymiary tego oleju na płótnie wynoszą bowiem $134 \times 178,5 \mathrm{~cm}$, a skromny format dzieła pozostaje w jaskrawej dysproporcji względem jego nad wyraz misternej i pojemnej konstrukcji.

Rama przedstawienia została skadrowana bardzo ciasno, co zwiększa wrażenie iście klaustrofobicznej atmosfery całości. Choć wydaje się to niemal niewykonalne optycznie - niczym w podkrakowskiej chacie na weselu - dzięki niezwykłemu kunsztowi malarza nie tylko we wnętrzu autobusu, ale i w samym obrazie zakomponowanych zostało i stłoczonych jedna przy drugiej ponad czterdzieści postaci. A skoro już o tym mowa, Autobus pod względem właściwego mu zamysłu artystycznego przywodzi jeszcze na myśl dwa inne wielkie dzieła polskiego modernizmu, mianowicie Melancholię (1890-1894) i Błędne koło (1895-1897) Jacka Malczewskiego.

Kilka słów o indywidualnym autorskim stylu tego dzieła. Przyjęto uważać, iż styl Linkego jest czymś na kształt jego własnej wersji realizmu metaforycznego. Nie do końca zgadzam się z tym, nieco zbyt ogólnikowym, określeniem. Przedstawienia metaforyczne (mówimy tutaj zarówno o tak zwanej małej, jak i wielkiej metaforze) w sztukach wizu- 


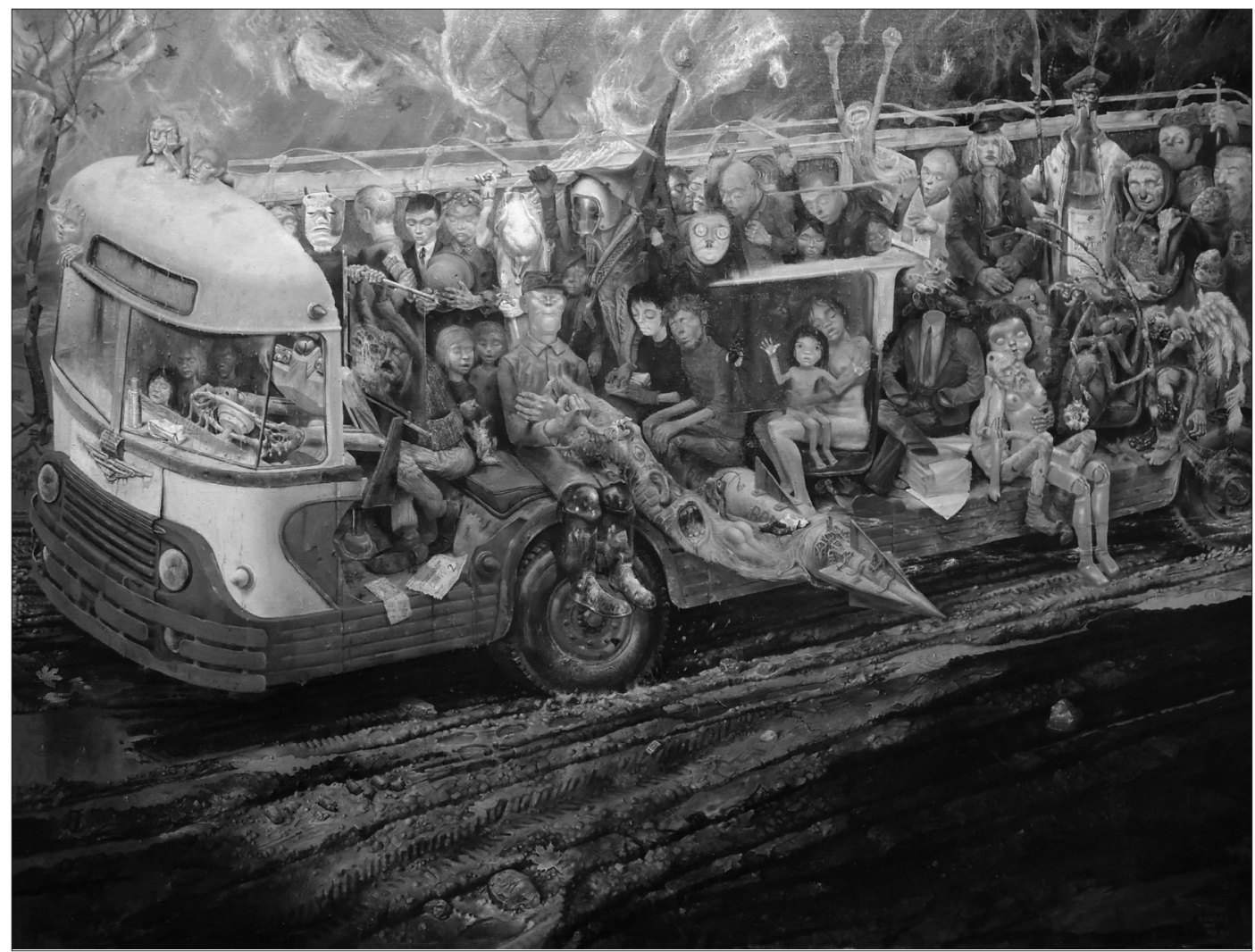

alnych mają to do siebie, iż zazwyczaj odwołują się do prezentowanego wprost konkretu. Konkret ten nie ogranicza się jednak tylko do sumy realiów ukazanych: w obrazie malarskim, filmie, fotografii, komiksie, rysunkowej karykaturze (kapitalny Kraków Andrzeja Mleczki, 2013) etc.

Narracja plastyczna Autobusu w mistrzowski sposób godzi w sobie zbliżenie i detal (stary bilet autobusowy, pudełko zapałek, paczka po papierosach, naklejka na flaszce spirytusu etc.) z planem ogólnym, zwanym w żargonie filmowym „total”. W zależności od kierunku interpretacji realia te można odczytywać na dwa odmienne sposoby: ad abstractum bądź ad concretum. Najbardziej nośna interpretacyjnie wydaje się jednak metoda pośrednia, kojarząca jedno z drugim i dostrzegająca głęboki związek oraz ambiwalentny charakter tego typu metaforycznych przedstawień[2]. Chodzi o to, iż każda ukazana rzecz (postać, sceneria, kostium, rekwizyt etc.) staje się w nich za sprawą przemyślnych zabiegów autorskich znakiem czegoś więcej. Dostrzeżona i zainscenizowana na obrazie w umiejętny sposób, okazuje się ona rzeczą-znakiem - nie dowolną jednak, jak w przypadku emblematu czy alegorii, lecz wyposażoną w szczególnego rodzaju atrybuty i kulturowe podteksty.

[2] W podobnej konwencji metafory wizualnej utrzymany jest również inny znany obraz Linkego z tamtego okresu, mianowicie Cyrk (1958). W roku
1963 obraz ten stał się tematem filmu o sztuce zatytułowanego Cyrk, nakręconego przez Konstantego Gordona. 
Właśnie tutaj i w ten sposób daje o sobie znać wizja malarska Linkego, z ogromną sugestywnością przemieniająca rzeczy w znaki. Sens każdego z takich wizualnych obiektów, które w ramach tego obrazu niosą z sobą jakiekolwiek znaczenie, zależy od sposobu ich malarskiego zaprezentowania. Idąc dalej tym tropem, odkrywamy, iż rdzeniem estetycznym zaprezentowanej w Autobusie wizji świata, jaki otacza samego artystę i nas, jest - konsekwentnie wydobyty przez malarza - turpizm jego przedstawienia.

Wywołany przez to efekt obcości prowadzi jednak do paradoksalnego w swej wymowie spostrzeżenia. Otóż szokujący tu i ówdzie turpizm Autobusu okazuje się dotyczyć czegoś bardzo bliskiego widzowi, a mianowicie zanurzonej w znajomym tu i teraz Warszawy końca lat 50. rzeczywistości, w której - nolens volens - żyją zarówno artysta, jak i adresaci przekazu. Chodziło zatem o to, by pokazać swoje jako obce. Dla obu stron przekazu ów znajomy świat - wraz z upiorną galerią zaludniających go figur - stanowi jedynie możliwe, ich własne otoczenie. Jest on właśnie taki. Innego nie mają, choć zapewne wielu o nim marzy.

Kartoteka postaci

Zgodnie z własnym przywiązaniem do realizmu w każdym szczególe Linke namalował warszawski autobus w dwu - już wtedy standardowych dla pojazdów stołecznej komunikacji - kolorach: żółtym i czerwonym. Nadał im jednak turpistyczny walor: na górze jadowita żółć, na dole równie przykra dla oka agresywna czerwień. Rzeczywistość, którą obserwujemy, znajduje się w stadium całkowitego rozkładu. Rozkład ten dotyczy zarówno ludzi, jak i rzeczywistości, w jakiej żyją (stąd obecność motywu błota, zgnilizny, gangreny i ślady pantofelków na podłodze i w całym wnętrzu pojazdu).

Wypełniający centrum obrazu pojazd pędzi po drodze nieco inaczej niż w rzeczywistości: z odjętym dachem i burtą. Widoczne są tylko rozpostarte na całej długości wehikułu ożebrowania konstrukcji dachowej. Przywilejem artysty i swoistym handicapem widza staje się w związku z tym przemyślnie zaprojektowany punkt widzenia, przynoszący percepcyjny efekt superpozycji. Dzięki temu umownemu zabiegowi możemy zajrzeć do wnętrza autobusu, przyglądając się dokładnie każdemu rekwizytowi i każdemu z jadących nim pasażerów.

Od swoich znakomitych poprzedników (Boscha, Bruegelów, Malczewskiego i in.) malarz przejął zasadę „wielkiego wzoru”, na podobieństwo fresku umożliwiającą artyście ukazanie dowolnie licznej grupy ludzi. W jego malowidle nie ma jednego głównego bohatera. Mamy tu do czynienia $\mathrm{z}$ dziesiątkami stłoczonych w autobusowym ścisku postaci i jednocześnie z wieloznacznym wizerunkiem zatomizowanejprzygodnie połączonej wspólnie odbywaną podróżą - zbiorowości, na którą pada przenikliwe spojrzenie autora obrazu. Wszechwidzące oko artysty wydaje się dostrzegać najdrobniejszy nawet detal i rys charakteru każdej z portretowanych osób, domagając się podobnie wyczulonej na szczegół spostrzegawczości u widza. 
Autobus nie daje się ogarnąć jednym, nawet najbardziej uważnym i wnikliwym spojrzeniem. Należy on do tych dzieł malarskich, które projektują skupiony, kontemplacyjny styl odbioru, organizując trajektorię spojrzenia - niczym kamera filmowa prowadzona od postaci do postaci i od szczegółu do szczegółu - na zasadzie zabiegu narracyjnego określanego w terminologii filmowej fachowym terminem repollero. Badacz studiujący ten niezmiernie pojemny znaczeniowo obraz musi w trakcie jego zgłębiania odpowiedzieć równie zaangażowaną i skupioną obserwacją.

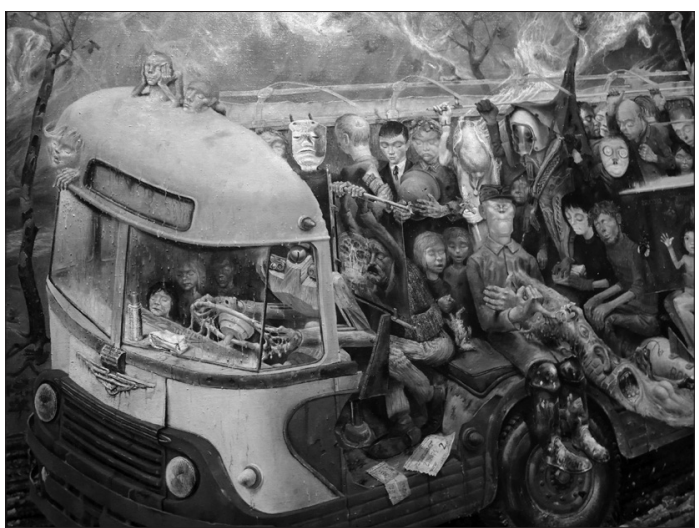

Spróbujmy przyjrzeć się przez chwilę każdej z ukazanych figur. $\mathrm{Na}$ froncie dachu nad szoferką widać dwa żółte popiersia ciał ludzi niczym ofiar w ruinach współczesnych Pompejów, organicznie wtopionych w żółtą karoserię. Za kierownicą autobusu siedzi manekin: antropomorficzna drewniana kukła bez głowy, trzymająca kierownicę martwymi dłońmi w stanie zaawansowanego rozkładu. Przed manekinem na pulpicie sterowniczym - termos i kanapki zawinięte w papier. To on prowadzi ten pojazd-widmo. W szoferce obok kierowcy - trzej mali pasażerowie o starych obliczach, wszyscy z zamkniętymi powiekami.

Za kierowcą i za taflą przegrody szoferki - mężczyzna bez twarzy, w modnych wąskich spodniach i czerwonych skarpetkach, trzymający się oburącz metalowego drążka. Za nim dwoje dzieci (jedno z nich trzyma za ogon zwłoki dręczonego kotka z głową w dół) oraz dwie postaci kobiece. U góry, nad nim, w drugim szeregu cztery dalsze postaci: kolejna głowa zasłonięta płaszczyzną dachu, obok niej maska diabła z czerwonymi rogami, młody „iblowski” inteligent z okolic pałacu Staszica z numerem francuskiego pisma artystycznego „Les Nouvelles littéraires", odświętnie ubrany z czarną aksamitką zamiast krawata, nieco dalej - młody człowiek w zielonym mundurze, trzymający w dłoniach przestrzelony hełm, oraz ekscentryczna postać $\mathrm{z}$ głową $\mathrm{w}$ kształcie cytryny, medalem na szyi i świecą komunijną w ręku.

Tuż obok sylwetka w hełmie kosmonauty, wewnątrz bezcielesna i wydrążona, w miejscu głowy nosząca maskę przeciwgazową, nad nią - wojskowy namiot pałatka do ochrony przed promieniowaniem, a poniżej - kolejna niepozorna postać ściśnięta w tłoku. Za to całkiem wygodnie na zniszczonym skórzanym siedzeniu autobusu rozsiada się prolet $\mathrm{z}$ rumianą zadowoloną gębą, $\mathrm{w}$ kombinezonie roboczym, robociarskiej czapce i zabłoconych, upapranych wapnem gumiakach. Wielkimi dłońmi wykonuje gest ,tu się zgina dziób pingwina” (w wersji dosadnej: „takiego wała jak Polska cała”), nazwany wiele lat później gestem Kozakiewicza.

W dół od zajmującej centrum figury proletariusza rozciąga się niczym strumień zastygłej lawy - przyklejona do nadgarstka jego prawej dłoni - wizyjna kompozycja złożona z fragmentów obalonego 


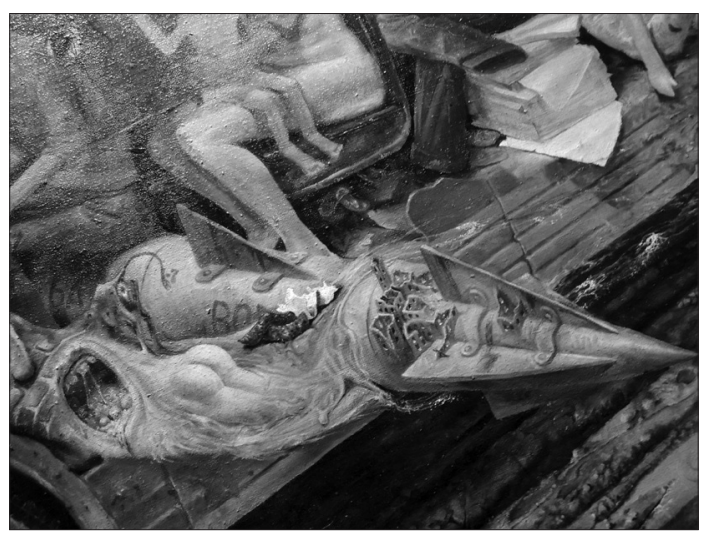

muru i zatopionych w nim (vide: wspomniany wcześniej motyw Pompejów): oka, ucha, krzyczących ust, gołych pośladków i ud oraz wypiętego krowiego zadu z uniesionym ogonem i czerwonym odbytem. Uzupełnia ją figura kopulującego psa. Poniżej, tuż przy dolnej krawędzi ramy obrazu, widać skierowany ku ziemi metalowy kadłub wielkiej bomby ze stożkowatymi sterownikami i częściowo zasłoniętym napisem BOM... i ostro zakończoną głowicą. U nasady sterowników kadłub bomby wlecze za sobą ruiny domów.

Konsekwentnie utrzymany wizyjno-halucynacyjny wyraz obrazu Autobus ogarnia swoim zasięgiem również wszelkie inne sportretowane w nim postaci. Mamy tutaj dwoje trzymających się za ręce młodych egzystencjalistów: modnie ostrzyżoną „na Simonę" szczupłą brunetkę w czerwonych balowych rękawiczkach oraz brodatego hamletycznego rudzielca w czerwonym golfie i wąskich dżinsach, z fryzurą „na Oliviera”. W drugim planie płótna widać ujętą en face postać $\mathrm{z}$ wąsikiem - ubraną $\mathrm{w}$ sutannę, $\mathrm{z}$ monetami zamiast oczu, oraz mężczyznę w żółtym swetrze czytającego gazetę. Ponad jego prawym ramieniem wyrasta wyprowadzona prosto $\mathrm{z}$ łamów gazety zagadkowa figura z rękami wzniesionymi ku niebu, przebita na wskroś drążkiem pasażerskiego uchwytu i wyrywająca się w górę na zewnątrz pojazdu.

Bliżej widza, w pierwszym planie: wyraziście wyeksponowana ramą okna autobusu, za szybą, siedzi pogrążona we śnie naga kobieta z nagim dzieckiem na kolanach (powrócimy jeszcze do nich w dalszych rozważaniach). Między wspomnianą parą młodych egzystencjalistów a nagą matką z dzieckiem - ogromna mucha łażąca po szybie. W prawo od tych dwojga - bezgłowy mężczyzna, elegancko ubrany (postać pusta w środku i bez butów), niczym cenzor siedzący na kilku ryzach papieru. Dalej młodziutka naga dziewczyna z woskową twarzą lalki, nagim biustem i drewnianymi nogami manekina, którą lubieżnie obłapia siwy staruch. Przy nich rozpycha się monstrualny insekt, wielki karaluch z komunistycznym orderem na odwłoku i parą długich czułków zwróconych w stronę kursu autobusu.

Wyżej, w dalszym planie, widać okazałą sylwetę krakusa w sukmanie, czapce z pawim piórem i z kosą osadzoną na sztorc. Zamiast spodziewanego wizerunku realnej osoby, w środku wydrążonej figury krakusa - litrowa butelka spirytusu rektyfikowanego z dokładnie widoczną etykietką i napisem „do użytku wewnętrznego”. W prawo poniżej karalucha odrażająca postać $\mathrm{z}$ osmalonymi i poszarpanymi skrzydłami, upadły anioł, niczym eksponat wyjęty z atlasu chorób wenerycznych - ma zaropiałą twarz i dwa ogromne wrzody widoczne na goleni oraz stopie drugiej bosej nogi.

Lekko w prawo i wyżej od karalucha stoi nędzarka $\mathrm{z}$ chustą na głowie i czerwonym nosem, obejmująca oburącz wielki okrągły bo- 
chen spleśniałego chleba i dźwigająca dwa inne worki pełne równie spleśniałego pieczywa. Nad babiną, po prawej ręce krakusa - śpiący mężczyzna z baczkami. Nad dziewczyną i staruchem - konduktorka z odmrożonymi dłońmi w kolorze fioletowym, z ostro wymalowanymi ustami i paznokciami, w charakterystycznej czapce konduktorskiej z tamtego okresu i z torbą zawieszoną na szyi.

Najdalej na prawo zamyka kompozycję czujna figura Stalina z przymkniętymi oczami, w mundurze generalissimusa, $\mathrm{z}$ nosem tuż przy spleśniałym chlebie nędzarki, z kratą więzienną w piersi i z zamurowanym (dosłownie!) sercem w miejscu orderów. Z kolei na szybie przegrody za kierowcą widać rozpłaszczoną na niej maskę (śpiącego lub martwego) Hitlera. Nieprzypadkowo złowrogie historyczne postaci obu katów dwudziestowiecznej Polski umieszczone zostały przez artystę po dwóch stronach obrazu. Hitler i Stalin tworzą w tym obrazie upiorny kontrapunkt namalowany w formie - znajdującego się nie na zewnątrz, lecz w środku autobusu, jadącego razem ze swymi ofiarami straszliwego tandemu dyktatorów ciemiężycieli.

Portret wyjątkowo mocny w osiągniętym przez malarza wyrazie. Mimo iż był mistrzem rysunku prasowego i karykatury (pamiętny plakat Aniołek podstuchiwacz, 1953), Bronisław Wojciech Linke unika jednak w swoim dziele łatwych efektów wynikających z przerysowania cech portretowanych postaci. Inaczej niż w późniejszym malarstwie Jerzego Dudy-Gracza, charakterystycznym dla kontrkulturowej ekspresji występującej w dekadzie Gierka, nie ma w tym zbiorowym portrecie Polaków lat 50. szyderczego, drwiącego spojrzenia na człowieka i społeczeństwo. Autor Autobusu nie uprawia łatwej w wymowie karykatury o charakterze publicystycznym. Jego dzieło, choć osadzone głęboko $\mathrm{w}$ realiach swego czasu, nie jest też satyrą na rodaków.

Sportretowana przez Linkego w tym wstrząsającym wizerunku rodzima zbiorowość okazuje się organizmem pogrążonym w zbiorowej malignie i upiornym letargu, chorym, znękanym, strudzonym mordęgą życia codziennego w nieludzkich warunkach, jakie zafundował im po wojnie najlepszy z ustrojów. W świetle wizji zaprezentowanej przez artystę stanowi ona społeczeństwo ludzi udręczonych i zniewolonych, o czym była już wcześniej mowa.

Zawarte w autobusowej panoramie krytyczne spojrzenie na to, co jest i jak jest czytaj: jacy naprawdę jesteśmy i jak wygląda nasza rzeczywistość - uruchamia w dziele niecodzienny rodzaj psychospołecznej empatii. Łączy się ono i koresponduje emocjonalnie z wyrozumiałym, współczującym traktowaniem własnego (to znaczy wspólnego nam wszystkim i samemu artyście) świata. Autobus nie szydzi i nie drwi z pasażerów. Okazuje się

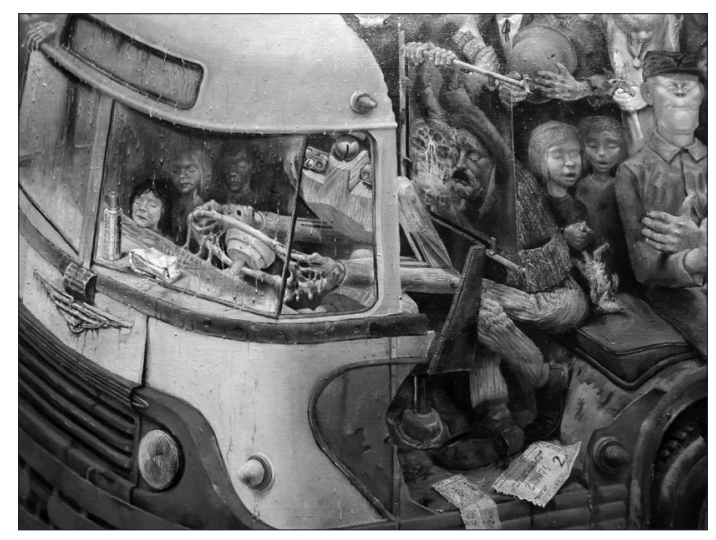

\section{Autobus jako karykatura}


on smutną i pełną goryczy parodią PRL jako topornego uniwersum parodią beznadziejnej, ułudnej, pełnej udręki codziennej egzystencji oraz nieludzkiego i utopijnego ustroju „sprawiedliwości społecznej”, na który zostały skazane miliony ludzi.

Linke zaczął malować Autobus w roku 1955. 22 lipca tego samego roku uroczyście oddany został do użytku dar narodów ZSRR - Pałac Kultury i Nauki w Warszawie. Istnieje widoczna zbieżność i pewna analogia, pozwalająca łączyć jego obraz nie tylko z tamtym monumentalnym założeniem architektonicznym, ale też z poetyką i ikonografią socrealizmu. Grupa kilkudziesięciu postaci sportretowanych na tym płótnie funkcjonuje na kształt szyderczej parodii malarskiej tamtego stylu ikonograficznego. Parodii, która okazuje się wizualną reminiscencją innej grupy: tworzącej sztucznie upozowany pierwszomajowy „żywy obraz”, przesuwający się na platformie podczas parady przed trybuną. Z tym, że w tamtym pochodzie obserwujemy odświętną atrape społeczeństwa totalitarnego, a tutaj mamy żywych ludzi i ich powszedni znojny dzień jak co dzień.

Daje o sobie znać jeszcze jedna zbieżność łącząca dzieło Linkego ze sztandarowymi budowlami realnego socjalizmu w stolicy. Dotyczy ona serii monumentalnych rzeźb wkomponowanych w architekturę Pałacu Kultury, MDM i placu Konstytucji, ukazujących emblematyczne postaci reprezentantów mas pracujących: cieśli, murarzy, robotników, górników, hutników, chłopów, matek z dziećmi itp. Analogicznie jak w Autobusie, czasem są to pojedyncze kamienne figury, czasem niewielkie paroosobowe ansamble.

Parodia, jakiej dokonał malarz, sięga wprost do poetyki tych rzeźb. Została ona ufundowana na demistyfikacji ich hieratycznego patosu. Artysta obramowuje wykreowane przez siebie ansamble, wyodrębnia poszczególnych ludzi i ich grupy nie po to, by „zmarmurzyć” swoich bohaterów w ideologicznej abstrakcji, lecz - przeciwnie - aby zaprezentować ich ciężki los. Tak odczytany, Autobus okazuje się przewrotną i niezmiernie nośną w swym wyrazie parodią i zarazem przenikliwą krytyką PRL, stylistycznie wyprowadzoną wprost z karykatury poetyki socrealizmu.

Chausson

Chausson nie jest zwykłym autobusem jakich wiele[3]. Z kilku powodów należy mu się po latach coś więcej niż sucha wzmianka. To legenda komunikacji warszawskiej - wehikuł z tekstem, i to jakim! Studiowana po latach historia Chaussona w Polsce stanowi niezmiernie ciekawy dokument swego czasu. W dziejach powojennej Warszawy autobusowi miejskiemu tej właśnie marki przypada miejsce tak znaczące i eksponowane, że śmiało może uchodzić za „tekst kultury”. Spróbujmy zatem przyjrzeć mu się bardziej uważnie, mając w pamięci przede wszystkim fakt, że autor interesującego nas obrazu nie tylko wyeksponował sam

[3] Zob. J. Dąbrowski, D. Nalazek, M. Stiasny,

Warszawskie autobusy i trolejbusy, Wydawnictwo

Betezda, Rybnik 2005. 
pojazd, ale także odmalował jego wizerunek z iście detaliczną dokładnością każdego szczegółu (liście na wietrze, tytuł czasopisma, porzucony bilet autobusowy na podłodze, rozjechany bidon, odpadki, ślady bieżnika odciśnięte w błocku na drodze itp.). Malarz, urodzony werysta, nie omieszkał też wyraźnie wykaligrafować znanej na całym świecie od XIX wieku marki najwyższej jakości opon: Dunlop.

Malując Autobus, Linke odwoływał się empatycznie do zbiorowego doświadczenia bardzo wielu ludzi. Dojeżdżanie w zrujnowanym mieście i kraju wiązało się z codzienną

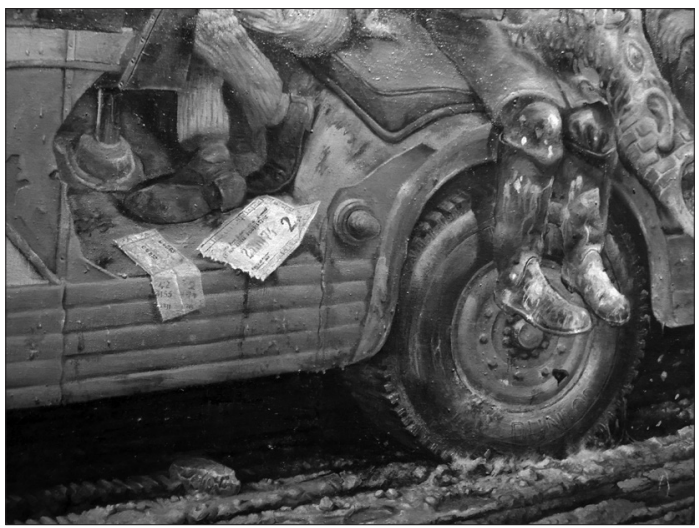
mordęgą milionów obywateli. Zanim chaussony pojawiły się na ulicach Warszawy, transport odbywał się w stolicy czym popadło. Autobusów i trolejbusów było jak na lekarstwo. Radzono sobie rozmaicie, głównie służyły do tego zdezelowane, pofrontowe ciężarówki, lory, riksze, platformy i furmanki. Luksusem i obiektem pożądania tysięcy mieszkańców, niczym w filmie De Siki, był zwykły rower. Nic dziwnego, że posiadanie własnego (a tym bardziej nowoczesnego) taboru komunikacyjnego stanowiło marzenie nie tylko stolicy, ale także bardzo wielu innych zniszczonych przez wojnę miast.

Produkowany przez renomowany francuski koncern o nazwie Société Anonyme des Usines Chausson, z fabrykami w Asnière-sur-Seine i Gennevilliers pod Paryżem, autobus oznaczony symbolem APH 47 uchodził wtedy za najlepszy na świecie. Do opinii tej przyczyniał się długi szereg technicznych rozwiązań: metalowe nadwozie samonośne, ekonomiczny silnik, niskie zużycie paliwa, przestronne wnętrze, składane drzwi z teleskopowymi drążkami, rewelacyjnie wytrzymałe osie, masywne zderzaki wykonane z szerokich płaskowników, niezawodne hamulce i doskonała chłodnica. Przede wszystkim jednak pojazdy te cechowała doskonała jakość wykonania, dzięki której wytrzymywały one nieprawdopodobne wręcz przeciążenia i najbardziej forsowną codzienną eksploatację.

Wbrew obiegowej opinii francuskie autobusy marki Chausson nie były Polsce podarowane, lecz zostały zakupione. Wspominam o tym, bo historia owego zakupu warta jest po dziesiątkach lat przypomnienia. W tamtym okresie zawarcie kontraktu handlowego na tak strategiczne dobro, jak paręset autobusów miejskich dla stolicy, pozostawało każdorazowo decyzją polityczną. Chausson był autobusem najwyższej klasy. Miał tylko jedną - ale niestety zasadniczą - wadę: produkowano go w kapitalistycznej Francji. Nic dziwnego, że pierwszych osiem chaussonów zaraz po przewiezieniu ich znad Sekwany wyjechało na ulice Warszawy wśród propagandowych fanfar i w pełni zrozumiałych zachwytów w dniu 22 lipca!

To, iż w latach 1947-1949 zakupiono dla Warszawy dwieście sztuk chaussonów, stało się możliwe nie z tego powodu, że wraz 


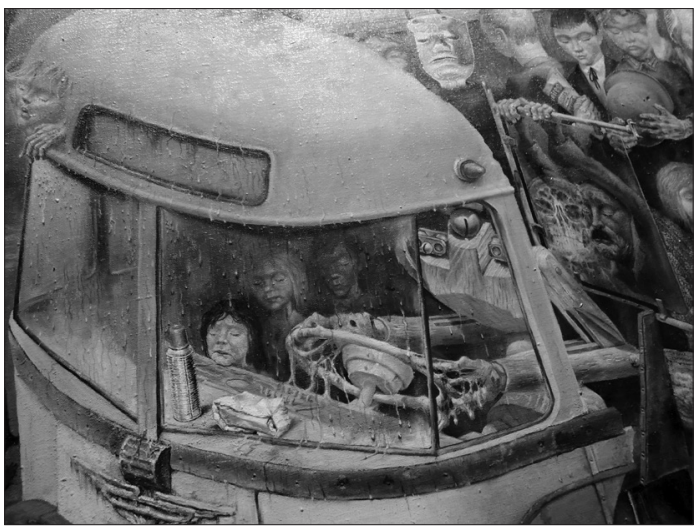

z nimi kupione zostały także trolejbusy vetra, lecz dlatego, że równocześnie z Francji sprowadzono dla władz bezpieczeństwa transport samochodów osobowych typu Citroën BL 11. Samochody te wkrótce zyskały złą sławę jako zapowiadająca nieszczęście szara i czarna „cytryna”. Tak przemyślnie „ubezpieczona”, transakcja zakupu pojazdów z imperialistycznego Zachodu miała więc ideologicznie charakter wiązany, skutecznie otwierając chaussonom drogę na warszawskie ulice.

W realiach powojennej stolicy autobus (zwany przez mieszkańców „hałsonem”) bardzo szybko stał się doskonale rozpoznawalnym dla wszystkich rekwizytem - budzącym pozytywne skojarzenia znakiem odbudowującego się miasta. Po przejściu przez propagandową rekwizytornię nowego ustroju wkrótce zyskał też stały epitet „Czerwony” - niczym Eos różanopalca i szybkonogi Achilles. Nie tyle zimny, obcy i obojętny pojazd mechaniczny, ile żywy organizm używany do masowego transportu i bezlitośnie eksploatowany każdego dnia. Oczekiwany na przystankach przez tłumy pasażerów. Zatłoczony, oblegany, wiecznie przeciążony...

Chausson pojawia się już w Skarbie (1948) Buczkowskiego, a potem $\mathrm{w}$ licznych filmach $\mathrm{z}$ lat 50 . Występuje też $\mathrm{w}$ dramatycznej scenie na kartach Złego Tyrmanda. Andrzej Łapicki w socrealistycznym dokumencie Jerzego Hoffmana i Edwarda Skórzewskiego Czy jesteś wśród nich? (1954), bolejąc nad zniszczeniami, jakich dokonują w warszawskich autobusach wandale, wypowiada zza kadru niezapomnianą retoryczną kwestię: „Poczciwe czerwone autobusy dopiero na cmentarzu porządnie odpoczywają”. Warto przy tym zwrócić uwagę na pełen sympatii i zarazem empatyczny przymiotnik „poczciwy”.

Kilkanaście miesięcy później, wiosną 1955 roku, czerwony autobus (ciągle na chodzie, choć nadal starszego typu, jeszcze z serii APH 49) stanie się kluczowym rekwizytem dokumentalnej impresji Andrzeja Munka pt. Niedzielny poranek. W chwili kiedy opuszcza rankiem stołeczną zajezdnię, kierując się w naszą stronę, narrator filmu głosem Kazimierza Rudzkiego wygłasza zza kadru pod jego adresem pełną wymownej adoracji kwestię: "Marzenie wszystkich warszawiaków. Mieć taki własny autobus, co?"

W obrazie Linkego, inaczej niż u Munka, Chausson APH 49 zostaje zastąpiony nowszą wersją. W ciągu kolejnych kilku lat, w okresie 1950-1953, kupowanie czegokolwiek od Francuzów stało się absolutnie niemożliwe. Dopiero w roku 1954, na samym początku politycznej Odwilży, dotarł do Warszawy kolejny transport zmodernizowanych chaussonów. Malarz uwiecznił w swym dziele właśnie jeden z nich: pamiętny model APH 520. Do jego charakterystycznych cech należała bardziej aerodynamiczna sylwetka, szeroko rozpostarte bocianie 
skrzydła na masce $z$ napisem Chausson i nadający wnętrzu pojazdu światowy posmak (odwrócony, a więc czytelny dla pasażerów w środku pojazdu) napis wytrawiony fabrycznie na szybie: „Issue de secours” (wyjście ratunkowe).

Gorzki jak piołun obraz Linkego można potraktować jako szyderczą glossę malarską do pewnej niezwykle przed laty popularnej piosenki. Nie jest dziełem przypadku, że wiele osób wypowiadających się na temat Autobusu (z Jackiem Kaczmarskim włącznie) posługuje się mimowiednie tytułem Czerwony autobus. Jeśli spojrzeć szerzej i odwołać się do intertekstualnych kontekstów płótna Linkego, to pojawią się nie tylko Wesele Wyspiańskiego, wspomniane płótna Malczewskiego czy Poemat dla dorosłych Ważyka. Oprócz tego nasuwa się jeszcze skojarzenie nie tylko o wiele bardziej bezpośrednie, ale i powszechnie znane dzięki swej obecności w kulturze popularnej PRL lat 50.

Chodzi o jeden z największych socrealistycznych szlagierów tamtych lat: piosenkę Czerwony autobus z muzyką Władysława Szpilmana i słowami Kazimierza Winklera. W najbardziej popularnym, klasycznym z wykonań, śpiewał ją z nieskazitelnie wyrazistą dykcją spiker radiowy, piosenkarz i aktor Andrzej Bogucki z towarzyszeniem Chóru Czejanda. I tak też, ta dziarska, optymistyczna pieśń dla mas pracujących została zapamiętana przez miliony ówczesnych Polaków. W latach 50. nie było chyba między Odrą a Bugiem nikogo, kto nie znałby słów:

Autobus czerwony przez ulice mego miasta mknie,

Mija nowe, jasne domy i ogrodów złoty cień.

Czerwony autobus to Mydełko Fa na antenie realnego socjalizmu. Bohater tej piosenki jest wzorcowym obywatelem PRL: skromny, bez wymagań, zadowolony z tego, co ma. Do życia potrzeba mu bardzo niewiele. Zachwyca się jazdą autobusem, rano przed pracą wystarcza mu do szczęścia uśmiech nieznajomej dziewczyny. Sądząc po głosie, nie wydaje się wprawdzie równie euforycznie szczęśliwy jak śpiewający pastuch z uwertury do filmu Aleksandrowa Świat się śmieje, który wręcz zanosi się śpiewem, a jeszcze do tego porywa pieśnią cały otaczający świat. Także nasz przeciętnie muzykalny obywatel Kowalski śpiewa o sobie w czerwonym autobusie, zanosząc się od upojenia urokami codziennego życia.

Aksamitny „przedwojenny” głos Andrzeja Boguckiego niesie z sobą oficjalnie obowiązujący, chciałoby się powiedzieć: urzędowy, optymizm, aplikowany masom budującym nowy ustrój. Lukrowany soc („w tej tonacji radości, w której serce moje gra”) tworzy poranną (akcja piosenki dzieje się rankiem, kiedy ludzie jadą do pracy) idyllę. Podczas gdy w obrazie Linkego na odwrót: utrudzeni, zmęczeni ludzie wracają do domów wieczorem. Sielanka piosenki Czerwony autobus zostaje w nim zastąpiona upiorną drastycznością każdego szczegółu malarskiej wizji.

\section{Piosenka \\ Szpilmana-Winklera}


Warto jeszcze przytoczyć końcowe słowa piosenki Szpilmana i Winklera, w kontekście obrazu Linkego nabierają one bowiem wielce przewrotnej wymowy:

Autobus czerwony, a w nim ludzie, choćby każdy z was.

Wszyscy patrzą, jakby pierwszy raz zobaczyli miasto swe.

\section{Kompozycja}

[4] Twórczość malarska Bronisława Wojciecha Linkego stała się dla Jacka Kaczmarskiego źródłem inspiracji także w innym wierszu, zatytułowanym Kanapka z człowiekiem (1981). 
cji zarówno wyższe piętro uogólnienia (los wspólny), jak i uplasowane na niższym piętrze paruosobowe ansamble, $\mathrm{w}$ ramach których dochodzą do głosu poszczególne mikrosytuacje, a wraz z nimi - kapitalnie uchwycone charakterystyki pojedynczych figur (los osobny). Spostrzeżenie to obejmuje swym zasięgiem bez wyjątku wszystkie sportretowane postaci, choć niekoniecznie dotyczy każdej z nich $\mathrm{w}$ równym stopniu.

Obraz Linkego nie ma wprawdzie głównego bohatera, ale kluczem do kompozycji malarskiej Autobusu okazuje się jedna -

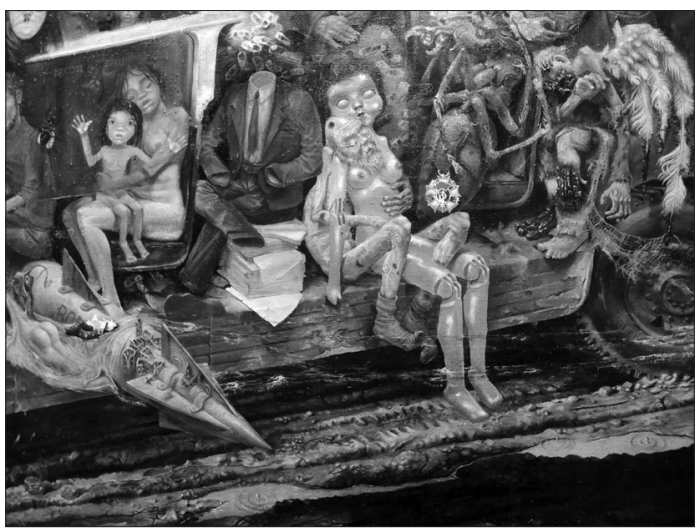
zdawać by się mogło całkiem niepozorna - postać. Nie jest nią ani kierowca-manekin, ani, wbrew swemu wyeksponowanemu usytuowaniu, opisany wyżej prolet z jego wulgarnym gestem odmowy. Aby zorientować się lepiej w zamyśle kompozycyjnym autora, trzeba najpierw postawić sobie pytanie: w jaką stronę skierowane są spojrzenia postaci w autobusie? Odpowiedź okazuje się zaskakująca: w żadną, wszystkie bowiem jadą nim z zamkniętymi oczami. Wszystkie, z wyjątkiem jednej.

Chodzi o szeroko otwarte oczy nagiego dziecka na kolanach matki. Właśnie ono zostało umieszczone w centralnym miejscu kompozycji całości i jemu przypada rola postaci nadającej jej główny akcent i ton. Nie jest dziełem przypadku, że dziecko i matka otrzymały z woli autora osobną ramę wewnętrzną w formie okna autobusu i że właśnie przy nich, obok głowy dziecka, widnieje odwrócony napis-komunikat: "Issue de secours". Trudno byłoby wskazać drugie dzieło portretowe, w którym malarz świadomie rezygnuje z namalowania wyrazu oczu uchwytnego w spojrzeniach portretowanych postaci. Nie ulega jednak wątpliwości, że wszyscy pozostali stłoczeni w autobusie pasażerowie mają oczy zamknięte i nie widzą (nie chcą widzieć? nie umieją zobaczyć?) rzeczywistości, która tak szczelnie wypełnia ich codzienną egzystencję. Na obrazie Linkego sprawa przedstawia się dokładnie odwrotnie i na opak jak w piosence Szpilmana: „Wszyscy patrzą, jakby pierwszy raz zobaczyli miasto swe".

Linke namalował zbiorowość umęczoną i pogrążoną w letargu. Z fotograficzną pamięcią każdego, najdrobniejszego nawet, szczegółu ukazał jej niewymownie prozaiczną codzienność i los. Tylko szeroko otwarte oczy dziecka zdają się widzieć otaczający świat „nagim spojrzeniem" peerelowskiego Kandyda i tylko jemu przypada z woli artysty ów wyraz porażającego zdumienia.

Kim był Bronisław Wojciech Linke? Życiorys Linkego nie jest biogramem powszechnie znanym, warto go więc w skrócie przypoSzkic do portretu mnieć. Artysta urodził się w roku 1906 w Dorpacie (estońska nazwa: Tartu). Jego ojciec, z zawodu notariusz, był szeroko znanym społeczni- 
kiem, nieformalnym liderem tamtejszej Polonii. Po odzyskaniu przez Polskę niepodległości Linkowie powrócili z Estonii do kraju i zamieszkali w Kaliszu. Przyszły twórca Autobusu rozpoczął studia plastyczne najpierw w Szkole Rzemiosł Artystycznych w Bydgoszczy, potem na Akademii Sztuk Pięknych w Krakowie. W latach 1927-1931 studiował grafikę i malarstwo w warszawskiej Szkole Sztuk Pięknych w pracowni prof. Tadeusza Pruszkowskiego.

Podczas studiów młody Linke został członkiem sławnej Loży Wolnomalarskiej. Z okresu przedwojennego pochodzą trzy cykle jego prac: Wojna, Miasto i Śląsk (seria znakomitych gwaszy). Warto je tu przywołać w kontekście studiów nad realizmem Autobusu, dostrzegając przy okazji pewną konsekwentnie biegnącą trajektorię rozwoju tej twórczości. Na artystyczną wyprawę na Śląsk malarz wybrał się wspólnie ze swoim bliskim przyjacielem Stanisławem Ignacym Witkiewiczem. Przedwojenne prace Linkego po większej części przepadły (kilka z nich znajduje się w kolekcji Muzeum Narodowego w Warszawie), zachowały się jedynie ich reprodukcje fotograficzne.

Po wybuchu wojny - jako artysta, którego nazwisko figuruje na listach proskrypcyjnych wrogów III Rzeszy (wielokrotnie publikował znakomite karykatury Hitlera) - we wrześniu 1939 ucieka przed hitlerowcami do Lwowa. Z tamtego okresu pochodzi porażający w swym osobistym wyrazie niewielkich rozmiarów obraz pt. Autoportret $w$ grudniowym Lwowie (1939, dzieło eksponowane obecnie na wystawie stałej Muzeum Narodowego w Warszawie). Deportowany w głąb terytorium ZSRR, spędził siedem ciężkich lat na zesłaniu w Orsku na Uralu. Dzięki usilnym staraniom wyciągnęła go stamtąd dopiero w roku 1946 Maria Dąbrowska.

Po powrocie do kraju Linke stworzył długi szereg prac, z których na szczególną uwagę zasługuje cykl Kamienie krzyczą (1946-1956), ukazujący tragedię Zagłady, a w okresie późniejszym - szereg doskonałych obrazów, między innymi Cyrk (1958) oraz Autobus (1955-1961). Z doktryną socrealizmu artysta miał na pieńku od samego początku jej zaprowadzania w Polsce. Po obejrzeniu obrazu noszącego tytuł Ural komisja kwalifikacyjna I Ogólnopolskiej Wystawy Plastyki (listopad 1949) odrzuciła pracę artysty w pierwszej eliminacji, umieszczając w protokole obrad kąśliwą uwagę: „malarstwo bardzo niedołężne”, skądinąd świadczącą o jej nader wyostrzonej czujności ideologicznej[5].

Jako twórca Linke nie potrafił kłamać. Uderzającą cechą jego prac jest wiarygodność artystycznej relacji, która łączy je z ukazywanym światem - wyrażająca się w przywiązaniu do konkretu. Nie chodzi tu bynajmniej o wierność zewnętrzną, rozumianą w kategoriach realistycznego odwzorowania wyglądów, lecz o wiarygodność wewnętrzną tych dzieł, wynikającą z poetyki doświadczenia, której artysta pozostał konsekwentnie wierny do końca. Nic dziwnego, że w okresie socrealizmu wybitny grafik i malarz popadł w niełaskę, przechodząc na pozycje

[5] Opinie Komisji Kwalifikacyjnej I Ogólnopolskiej Wystawy Plastyki o pracach przejrzanych $w$ pierwszej eliminacji, w: Nowocześni a socrealizm, t. 1, red. M. Świca i J. Chrobak, Fundacja Nowosielskich,

Starmach Gallery, Kraków 200o, cyt. s. 365. 
twórcy pracującego bez rozgłosu i niemal nie wychodzącego poza krąg najbliższych przyjaciół.

Przez następne lata Linke niemal nie wystawiał i nie pokazywał swych prac, ograniczając własną aktywność twórczą do wnętrza pracowni. Jego „bardzo niedołężne” malarstwo stanowi dzisiaj jeden z koronnych dowodów na to, iż sztuka polska za czasów PRL zdołała mimo wszystko zachować rozległy margines wolności i wyrazić za pośrednictwem niezmiernie nośnej parodii malarskiej należny dystans i krytyczny stosunek do świata, w którym na co dzień żyli - dzieląc swój los ze zwykłymi ludźmi - wybitni artyści.
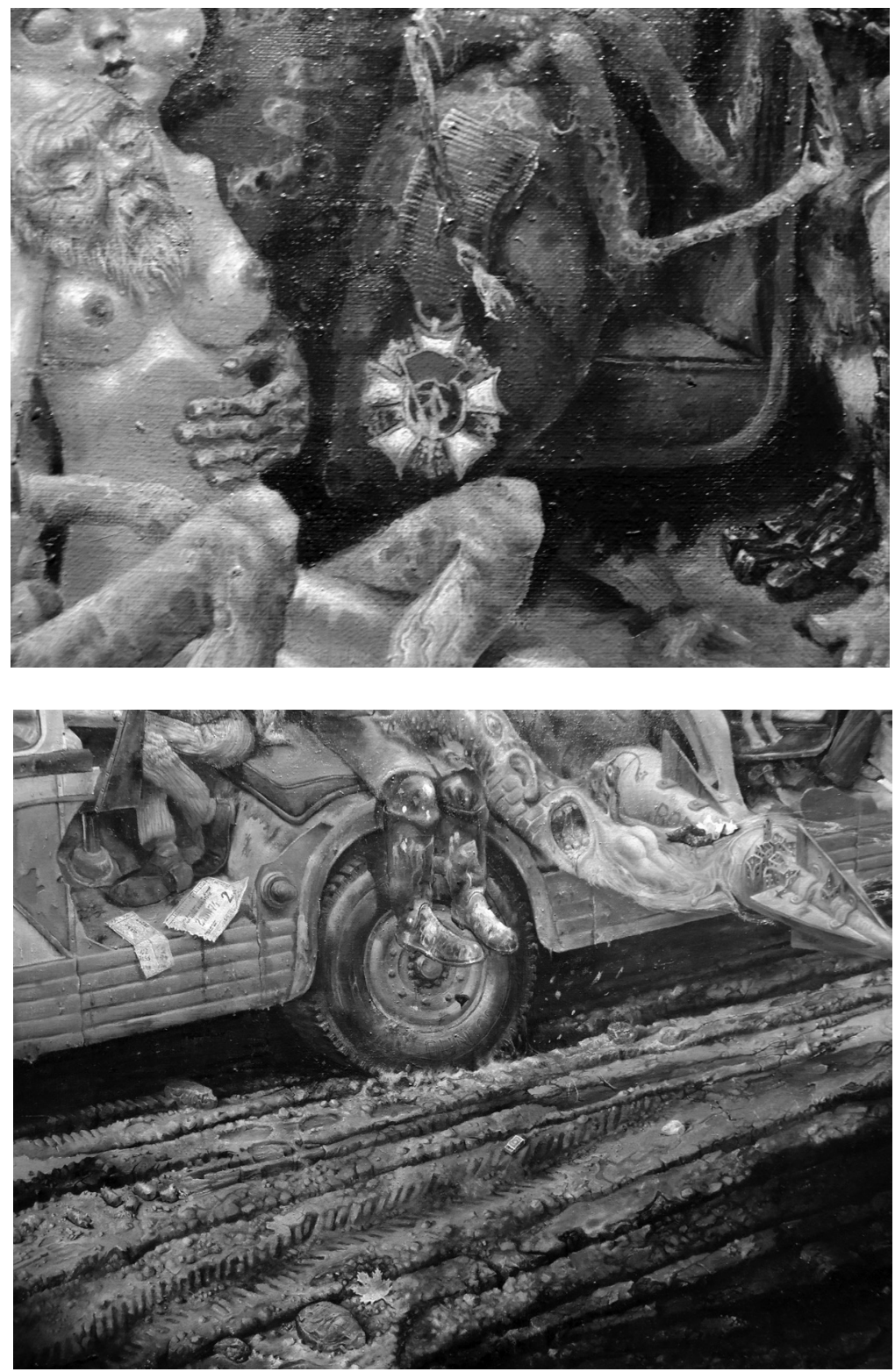